\title{
Illustration and Text Comprehension: Tales Study for Primary Students
}

\author{
Faustin Mounguengui ${ }^{1} \&$ Samuel Nyock Ilouga ${ }^{1,2}$ \\ ${ }^{1}$ Department of Psychology, Omar Bongo University, Libreville, Gabon \\ ${ }^{2}$ Department of Psychology, Yaounde I University, Yaounde, Cameroon \\ Correspondence: Samuel Nyock Ilouga, Department of Psychology, Yaounde I University, Yaounde, PO Box: \\ 13084 Douala, Cameroon. Tel: 237-698-795-848. E-mail: nyock.ilouga@gmail.com
}

Received: April 18, 2019 Accepted: May 9, 2019 Online Published: May 25, 2019

doi:10.5539/jedp.v9n1p90 URL: http://doi.org/10.5539/jedp.v9n1p90

\begin{abstract}
Essential for the individual's successful adaptation in the society, text comprehension is a cognitive activity more and more complicated to the child (Blanc \& Brouillet, 2005). However, these understanding difficulties get better with the age (Boisclair, Makdissi, Sanchez, Fortier, \& Sirois, 2004; Segui \& Léveillé, 1977). The present study, working on the principle that illustration is beneficial to the comprehension process (Ammari, 2015; Blanc \& Tapiero, 2002; Gyselinck, 1995, 1996; Gyselinck \& Tardieu, 1993; Reinwein, 1988; Rizk Batien, 2009; Vezin, 1986), has proposed to study the effect, the role of this one on comprehension to the children through tales. Two groups of students aged from 7 to 9 years old read two short stories, illustrated or not. Two tests were also submitted to them: the task of understanding and highlighting important words and/or ideas. The results obtained show clearly the positive effect of the illustration on the students' performances and testify thus to the fact that illustration can be used as a palliative to the understanding difficulties of to the children.
\end{abstract}

Keywords: text comprehension, Illustration, ales, Child low case

\section{Introduction}

The final purpose of reading is the comprehension of text (Potocki, Bouchafa, Magnan, \& Ecalle, 2014). The learning of this one is an issue of primary importance in so far as the knowledge to read is an essential basic skill (Eme, Reilly, \& Almecija, 2009). If the existence of two components involved in the act of reading is classically accepted (Aaron, Joshi, Gooden, \& Bentum, 2008); namely the identification of written words as the first component and the semantic and syntactic processes involved in the processing of successive sentences and the highest level of integration processes of all textual information in a single coherent representation allowing the construction of a mental model, as a second component, it is on this second component that our interest is concerned.

Of course, the research focus of text comprehension is to study the meaning given to the text by the reader. It is a question of showing how the text treated and the situation described is represented and kept in memory, that is to say, to give an account of both the nature of the representation, its content and finally the processes at the origin of its construction and evolution (Glenberg \& Mathew, 1992). In this sense, even beyond reading, text comprehension is considered as a critical cognitive activity for the individual. It is guided by the need for the reader to maintain both the local and global coherence of the text (van Dijk \& Kintsch, 1983). Its purpose is also to focus on the cognitive representations, procedures and mechanisms that the individual implements when engaged in this type of activity (Blanc \& Brouillet, 2003).

Moreover, Ecalle and Magnan (2010), like many other authors, argue that current data indicate that a high percentage of primary school pupils have difficulties in this area (Gernsbacher, Varner, \& Faust, 1990; Oakhill 1991; Zabrucki \& Ratner, 1986; Zérillo \& Brouillet, 2002). However, a low level of reading comprehension suggests more general academic difficulties. According the idea that the illustrations have an essential role, beneficial in the text comprehension (Ammari, 2015; Blanc \& Tapiero, 2002; Glenberg \& Langston, 1992; Gyselinck, 1995, 1996; Gyselinck \& Tardieu, 1993; Gyselinck, Levie, \& Lentz, 1982; Jian \& Ko, 2017; Reinwein, 1980, 1988; Rizk Batien, 2009; Schallert, 1980; Vezin, 1986), the present study proposes to see if the use of illustration through the reading of tales in children could not constitute a relevant advantage by a better comprehension and thus to palliate some difficulties inherent to it among them. 


\subsection{Theoretical Framework}

To understand a text is to develop a coherent mental representation. It is therefore necessary to extract meaning. Indeed, as soon as the individual is confronted with written or even oral information, he is supposed to develop in memory a representation that derives from the information he has just processed (Bransford, Barclay, \& Franks, 1972; Kintsch, 1993; McNamara \& Kintsch, 1996). For Blanc and Brouillet (2003), it is an activity by which the individual uses and acquires knowledge. It can also be seen by Marin and Legros $(2008$, p. 62) to be conceived both as "a mental activity of construction of the meaning of the text and as the product of that activity, that is, the meaning of this representation". It is widely accepted that the reader's knowledge determines the text comprehension and memorization (Mannes \& Georges, 1996; Moravcsik \& Kintsch, 1993) and this, through many processes (Rossi, 2008; Zwaan \& van Oostendorp, 1993). Otherwise, scientists agree that it is a complex activity involving different sources of information (Blanc, 2009; Giasson, 1996). In this sense, the representation is the product of the interaction between the text, the reader's knowledge and the information both prior and recent that he discovers as the reading progresses.

For this purpose, text comprehension is a selection activity. The reader must be able to remove irrelevant information, of course taking into account context, constraints and reading objectives. Thus, the individual elaborates in memory a coherent representation of the situation described by the text; representation, supplemented by inferences produced during reading that meet its objectives, which are defined in context (Blanc, 2009a).

In summary, text comprehension can be defined as a dynamic process of construction in memory of a coherent representation of the situation to which are added the general inferences, within the limit of the attentional resources of the individual (Blanc \& Brouillet, 2005). To understand a text requires to be able to integrate into a coherent whole the information described and the knowledge activated; to be flexible in adapting to the described situational context and highlighting the most relevant features of the situation; and also select, from all the information, those that are most relevant and / or most appropriate to the success of the comprehension process. However, can one understand the comprehension of texts in an adult individual to that in a child?

If text comprehension is a complex cognitive activity, it can rightly be predicted to be more so in the child than in the adult. Many arguments in fact support this situation. The child is a developing being. As a result, it tends towards maturity and especially towards maturity on the cognitive level. On this subject, moreover, the hypothesis of departure postulates that in the framework of the comprehension of texts, with the age the children take into account a growing number of syntactic indices (Segui \& Léveillé, 1977). It is therefore with advancing age that children can better understand the stories.

Some children are very early immersed in the world of writing and books. They benefit from hundreds of hours of interaction with their parents during which they develop a familiarity with the written language and improve the quality of their understanding. Others, on the other hand, can only rely on the school and if it can not devote the same number of hours, it can, however, offer specific and explicit teaching and thus compensate for early social inequalities (Cebe, 2013). Overall, children have difficulty understanding text. These may be due to the difficulties of decoding words (Gernsbacher, Varner, \& Faust, 1990; Yuill \& Oakhill, 1991), although these difficulties do not concern the information present in the texts (Cain \& Oakhill, 1999). Zérillo and Brouillet (2002) have also highlighted these difficulties of comprehension in children because of the difficulty they have in extracting important information because, according to Symons and Pressley (1993), even in the adult reader, the selection of relevant information relies primarily on the knowledge of the latter.

Moreover, understanding does not automatically take place when the decoding of words is efficient. It is a function of different abilities and may require specific learning. For this purpose, it can be influenced in children by many factors. Thus, for example, the speed with which children access the meaning of words, which increases with age and precisely between 8 and 10 years of age (Chabot, Petros, \& McCord, 1983) is a very determining factor because, it leads to the richness of their vocabulary. It is also influenced by the ability to identify the main ideas, with the idea that even the youngest ones provide more important information than unimportant. Finally, the ability to generate inferences is also characteristic of advancing age because, even when knowledge is present in children, they do not necessarily indicate that they make inferences (Barnes, Dennis, \& Haefele-Kalvaitis, 1996).

So no, as Cèbe asserts (2013), the comprehension of texts is not a "children's game" and it is not automatic. It is a complex activity that relies on the simultaneous implementation of many skills. It is in this that it presents more difficulties in the child than in the adult individual. However, recent work emphasizes the need and even the possibility of developing skills to understand written texts from an early age, without waiting for word identification processes to be installed. For this reason, knowing that tales and fables make it possible to transmit to children the values of life and have a very important function in their psychological evolution, we proposed to see 
if the illustration through the comprehension of stories was not an asset to circumvent certain difficulties of comprehension.

So no, as Cèbe asserts (2013), the comprehension of texts is not a "children's game" and it is not automatic. It is a complex activity that relies on the simultaneous implementation of many skills. It is in this that it presents more difficulties in the child than in the adult individual. However, recent work emphasizes the need and even the possibility of developing skills to understand written texts from an early age, without waiting for word identification processes to be installed. For this reason, knowing that tales and fables make it possible to transmit to children the values of life and have a very important function in their psychological evolution, we proposed to see if the illustration through the comprehension of stories was not an asset to circumvent certain difficulties of comprehension. Indeed, through storytelling, children know the clash between good and evil, and they learn to choose the right. They explain to them with simplicity the things of life. According to Bettelheim (2008), the story recounts all the buried aspects of our impulses, fears and fantasies. And it is by reading stories to our children that we speak as freely as possible. In fact, some people say that telling stories, reading stories to children, preserves and preserves one's own traditions and culture. In addition, Barriault (2016) says that experts have discovered that reading stories and stories has a significant influence on children's understanding of the world in which they live. In addition to participating in the development of the literary skills of the child, they are vehicles for the values, beliefs, attitudes and social and cultural norms that shape their conception of reality; hence our interest in this tool.

As for the illustration, and precisely the illustration in the comprehension of texts, the main question that lies behind the study of the link between these two notions is that which Reinwein (1988, p. 36), "Is it easier to understand an illustrated text than its non-illustrated version?" If the answer as it is in advance seems to be yes obviously because, whether the reader is beginner (child) or experienced, the illustration can have a positive effect on his understanding, the contours and incidences of the latter seem much less obvious and therefore more complex to pin down. Illustration may influence text comprehension and thus may or may not have a beneficial role as some previous studies have shown (Ammari, 2015; Gyselinck, 1995, 1996; Gyselinck \& Tardieu, 1993; Gyselinck, Jamet, \& Dubois, 2008; Jian \& Ko, 2017; Levie \& Lentz, 1982; Reinwein, 1980, 1988; Rizk Batien, 2009; Vezin, 1986). It is a form of help given to the reader for the construction of the pictorial representation and the apprehension of an overall view of the text (Vezin, 1986). In connection with our study, we must better understand illustration as a diagram that graphically expresses the consequence of an action. This procedure, which consists in reinforcing a text, is very often used in educational systems to promote school learning among pupils or students (Vezin, 1984; Brody, 1981, cited by Vezin, 1986); which reinforces our approach. Thus, in illustration as a factor, more recently, studies that have examined the role of illustration in textual understanding have provided a body of empirical evidence suggesting a beneficial effect on the highest levels of literacy and the most expensive of language comprehension, more particularly on the ability to produce elaborate inferences (Gyselinck, Jamet, \& Dubois, 2008). In fact, there seems to be a consensus that illustrations have a beneficial effect on text comprehension (Gyselinck \& Tardieu, 1999). In this sense, they improve the comprehension of the illustrated information of the text compared to the text alone (Levie \& Lentz, 1982). Moreover, this facilitating effect is observed both for the narrative text and for the informative text, even though the illustrations provide redundant information in relation to the text. Also, several theories have been elaborated and allow for this to reinforce the idea that the illustration would positively impact the memorization of textual information. This is the case of Pavio's (1986) double-coding theory, whose relevance to the objectives we are pursuing has been proven (Paivio \& Lambert, 1981 see Rizk Bastien, 2009), despite some advanced reservations, which have illustrated that illustrations could also play a role beyond the mere function of information retrieval (Waddill \& McDaniel, 1992). The illustrated textual information would be doubly encoded, which would then have a positive impact on the memorization. Thus, according to the double coding theory, all cognition involves the activation of two systems of symbolic representation, namely the verbal system and the nonverbal system. Although interconnected, the two systems are structurally and functionally independent, resulting in an additive effect of the two codes, verbal and non-verbal, on the recall.

Finally, like many other factors, namely the readers' knowledge, their ideologies, their motivations, their expertise, their motivations, their goals, the illustration is a cognitive data essential to understanding the message that is delivered by the text. It allows to direct the activity of the individual towards the complementary use of the two modes of expression (verbal and illustrative). The illustration thus has an objectivation value which facilitates the pictorial representation. According to Vezin (1986), the illustration has many characteristics. It has a concrete character because it specifies a concept, an informative value through semantic correspondence and it finally offers a freedom of reading illustrations, in the sense that the same image for example could give rise to several readings. However, and this is where the problematic of this work lies, we have therefore proposed to study the effect of 
illustration on students' understanding of stories. Several major theoretical considerations that we have already mentioned for some have led us to this goal. First of all, for the understanding that is considered to be a source of difficulty for children, storytelling is a relevant tool for evaluating it. Also, many works have shown that the illustrations have a facilitative role on the comprehension of texts, and could in this way overcome some difficulties. For this, we have formulated the general hypothesis that the illustration positively influences the process of understanding short stories in students. When tales are illustrated, understanding is better than when they are not.

\section{Method}

\subsection{Participants}

Fifty-two (52) students in the third year of primary school, including 33 girls and 19 boys, from Mindoubé Public School (in the Libreville-Sud school district) aged between 7 and 9 years old took part in our study. We therefore formed two (2) groups of twenty-six students.

\subsection{Measures and Covariates}

We used two Gabonese children's storytelling from the Gabonese storybook published by Presence Africaine in 1967 of Raponda-Walker. The tales chosen are : « la pintade et le caïman » and « la mère-poule et l'épervier ». In addition to the tales, the experimental material also consisted of a text training, to become familiar with the experimental procedure, sheets of paper and pens for comprehension tasks and a stopwatch to measure reading time.

\subsection{Experimental Manipulations or Interventions}

The experiment began with the reading of the training text so that the reader becomes familiar with the procedure. The stories were presented both on computer (Phase 1: reading) and on paper (Phase 2: highlight important words or ideas), and they were read one after the other in a random order. The instruction given was: "You will now read two stories, one after the other. Read them carefully so that you can answer comprehension questions immediately afterwards. Read at your own pace but tell us as soon as you finish reading, thank you.

Two tasks were submitted to the participants: a first task called comprehension task composed of four questions. They were already mentioned on paper and each child, after reading each tale, just had to indicate his answers; and a second task which consisted for each student to whom the story was written on paper (Phase 2), to emphasize the words and / or important ideas of the tales he had just read. We also measured reading times in seconds (S).

\section{Results}

The manipulated factor is the presentation of texts with or without illustrations. To analyze the data obtained and to test the working hypothesis formulated, using the Statistica software, an analysis of variance (Anova) was calculated on the measured indicators that are the reading times (in seconds), the performances with the task of understanding and the general ideas emphasized. This was done according to the following experimental design: $\mathrm{S} 52<\mathrm{A} 2>* \mathrm{~B} 3$, where $\mathrm{S}$ corresponds to participants, $\mathrm{A}$ to both experimental conditions and $\mathrm{B}$ to measured performance.

\subsection{Statistics and Data Analysis}

Table 1. Average performance of students by reading status

\begin{tabular}{llll}
\hline Reading situation & Time to reading in seconds & Understanding of tales & General ideas underlined \\
\hline With illustrations & 363.61 & 0.76 & 0.75 \\
Without illustrations & 277.76 & 0.73 & 0.59 \\
\hline
\end{tabular}

The descriptive analysis of the results in the table above shows differences in student performance according to whether they read the texts with or without illustration.

In terms of reading time, participants who read the stories with the illustrations ( $M=363.61$ seconds) take longer to read the stories than those who read the same texts but without illustrations ( $\mathrm{M}=277.76$ seconds). Readings with illustrations mean that participants take longer to read the texts than reads without illustrations. This seems to be coherent because it must be considered here that the illustration is an additional task, it would then weigh down the cognitive treatments and therefore the reading time of the students. 
For performances at the comprehension task, participants who read the tales with the illustrations perform better scores on average $(M=0.76)$ than those who read these same tales without illustrations $(M=0.73)$. In this sense, the illustrations allow students to perform better and thus better understand the texts than those who have not read the texts with illustrations. It thus facilitates the process of understanding through better performances in the participants. As for the task for students to highlight important ideas, again, students who read the tales with the illustrations $(\mathrm{M}=0.75)$ emphasized the general ideas more than those who read the same tales without illustrations $(\mathrm{M}=0.59)$.

The descriptive analysis of the results shows indeed better performances for the participants having read the tales with illustrations than without illustrations. As a result, we can already say that there is an effect of illustration on students' understanding of storytelling. However, are these differences significant?

\subsection{Inférential Analysis}

The overall analysis of the results indicates a significant effect of the illustration variable on students' performance in story comprehension $[\mathrm{F}(3-48)=67.22 ; \mathrm{p}<0.05]$. In other words, the illustration factor impacts the understanding performance of the participants.

It also indicates a significant effect of the illustration variable on the reading times of the participants $[\mathrm{F}(1-50)=$ 194.91; $p<0.05$ ]. For that, reading tales with or without illustrations is totally different. Indeed, the illustration is an additional data that generates even more cognitive treatments requiring time, which differs from reading without illustration. It is for this reason that participants who read with illustrations are less effective, less rapid in their reading than those who read without illustration. As a result, it seems consistent. The illustration here by the times it increases does not constitute a positive influence on the reading of stories. Performance in comprehension then seems more appropriate for such an objective.

Thus, for performance in comprehension (Comprehension task), the analysis indicates that there is no significant effect of the illustrative variable on these [F $(1-50)=0.09 ; p=0.75]$. In other words, although the students who read the tales with illustrations perform better than those who read the same tales without illustrations, the difference observed is not significant. The performances are therefore not linked to the presence or absence of illustrations during the reading. The illustration should not be perceived here as a help for participants for a better understanding.

Finally, concerning the important words or ideas underlined, the analysis indicates a significant effect of the illustration variable on this skill $[\mathrm{F}(1-50)=6.80 ; \mathrm{p}<0.05]$. In other words, the ability for these students to identify important words or ideas is modulated by the illustrations. When the stories are illustrated, students are therefore more apt at being able to emphasize these important words or ideas.

\section{Discussion}

The purpose of this study was to test the effect of illustration on short stories comprehension in students. It was a question of knowing if the comprehension of a tale when it was illustrated, was better than when it was not, and thus to consider the illustration as improving certain difficulties of comprehension in the child. Overall, the results obtained are very clear. They make it possible to reinforce the hypotheses formulated, insofar as they indicate an influence of the illustration on the process of comprehension. They almost all tend to be consistent with many previous studies (Ammari, 2015; Glenberg \& Langston, 1992; Gyselinck, 1995, 1996; Gyselinck \& Tardieu, 1993, 1999; Gyselinck, Jamet, \& Dubois, 2008; Levie \& Lentz, 1982; Reinwein, 1988, 1980; Rizk Batien, 2009; Schallert, 1980; Vezin, 1986), who provided us with a theoretical framework and highlight the decisive role of illustrations in the product of understanding.

First, being in agreement with the idea that there are more difficulties of understanding in the child than in the adult, it must be said that the story is a relevant tool to evaluate it. Characterized by his wealth, the storytelling is a really fiction. It's a short story, sometimes fantastic, whose the narrative framework is a little bit complicated (Hollemaert, 2013). Indeed, storytelling can be considered as stories and in this sense, many studies (Blanc, 2009b, 2010; Boisclair, Makdissi, Sanchez, Fortier, \& Sirois, 2004; Makdissi \& Boisclair, 2004a, 2004b), by this tool, had showed some inherent habilities to the development. In the sense which, they argue that it is gradually to the child in prescholary age, that slowly some mechanisms appear and he is going to appropriate and using different situational dimensions in tasks comprehension.

While the results we have obtained agree in their entirety with previous work that clearly highlights the facilitating role of illustration in the comprehension of texts, it should be noted that this was not the case for those obtained by the comprehension task. Although the performances of the students who read with illustrations are better than those of those who read without illustrations, this difference is not significant. It can not be explained by the 
presence or absence of illustrations. How then to understand, explain and discuss these results? With respect to the fact that performance on the comprehension task is not consistent with our expectations, it is possible that most subjects have specific knowledge of the situations described by the stories, and that the illustration does not allow in this respect case of improving performance. Students must be able to develop a coherent representation based on their knowledge (Blanc \& Brouillet, 2003; van Dijk \& Kintsch, 1983), and of course, the pupil's level of education has an impact on his performance in comprehension (Potocki, Bouchafa, Magnan, \& Ecalle, 2014). Moreover, Gyselinck and Tardieu (1999) have shown that in the case of a lack or insufficiency of knowledge, the mental model does not reach a level of elaboration sufficient for the illustrations to strengthen it. Thus, the lack of significant difference in knowledge certainly evoked by the tales, makes that the illustrations do not improve the performances. Consequently, we must be able to dissociate performance and intelligence in these students, in the sense that the performance is considered to follow the intelligence.

Also, these results resonate with some other theories that tend to explain cognitive performance in textual comprehension over illustration although developed from adult readers. This is notably the case of Glenberg and Kruley (1992) and the work done by Glenberg and Langston in 1992. For the latter, the participant's performance is superior, that is to say better when the text is accompanied an illustration. In the study by Glenberg and Kruley (1992), the illustrations represented the structural relationships between the parts of the object described in the text and focused more specifically on the role of illustration in the resolution of anaphors classified in inferences of links. However, to build these inferences, the reader does not use his personal knowledge. It thus appears that the illustration does not promote the resolution of anaphoras either. For this purpose, if the illustration has a facilitating role in the comprehension of texts, it would be limited. Glenberg and Langston (1992) also worked on the effect of illustration, showing its facilitating role. Only the fact that we have worked on stories and with children forces participants to refer to what they are, to their knowledge, to their abilities in relation to the stories read.

In addition, the term multimodality is used more, to describe a better efficiency of cognitive performance, our results tend to confirm that. For this, we agree with Jamet (2002), when he argues that these new opportunities do not necessarily translate into improved performance. Thus, Jamet, Le Bohec and Hidrio (2003) argue that one of the most common reasons is the overloading of the cognitive system that does not promote the effectiveness of treatments during a task. For this purpose, although the role of the illustration is to help students memorize the ideas of the tales in another form, this result can also be explained by the fact that in this case, the illustration would rather overload the memory of the child (Jamet, Le Bohec, \& Hidrio, 2003) and he would then have two separate pieces of information to deal with: one in the verbal form, the other in the pictorial form. Thus, to answer the questions of comprehension, the participants would use both forms of information and there would then be at the cognitive level an extension of the treatments. However, if this result is secondary, it is because all the other results show the opposite and tends to reinforce our expectations. Indeed, student performance are better overall when reading illustrated stories than when they are not.

Thus, despite the idea of the difficulties which is peculiar to their comprehension (Blanc, 2009a; Gernsbacher, Varner \& Faust, 1990; Yuill \& Oakhill, 1991; Zabrucki \& Ratner, 1986; Zérillo \& Brouillet, 2002), the pupils succeed very well good at the task of emphasizing general words or ideas regardless of illustrations. Such a result shows that it is relevant to speak of cognitive development. Indeed, the students involved here are between 7 and 9 years old. At this age, many reading and comprehension skills are already present (Blanc, 2009a). Admittedly, knowledge is progressively structured and cognitive activities are even prior to language acquisition, but between 8 and 10 years old, the speed with which children access the meaning of words increases (Chabot, Petros, \& McCord, 1983), which can explain this success. Subsequently, this success is better for students who read the tales with illustrations than for those who read them without illustrations. Paivio's theory (1986) is therefore relevant to give meaning to these results. Indeed, it makes it possible to explain clearly the positive effect of the illustrations in tasks of cognitive elaboration. Already having some skills, the performance of students reading storytelling with illustrations increases because double coding (one in verbal form and the other in mental picture form) instead of being an additional cognitive load, is a definite advantage, a facilitator of treatments. In addition, it should be noted that the story is a story. It is a very relevant tool for assessing children's comprehension because, as Hollemaert (2013) points out, it is strongly suggestive for the latter that he participates in the development of his personality and even his socialization. And many authors are using storytelling in their studies as a pertinent material (Blanc, 2009b; Blanc, 2010), to measure the text comprehension of children.

The acquisition of knowledge, which promotes a better understanding (Blanc \& Tapiero, 2002; Glenberg \& Mathew, 1992; Kintsch, 1993, Mannes \& Georges, 1996; McNamara \& Kintsch, 1996; Zwaan \& van Oostendorp, 1993), and even Cognitive functioning in children is a dynamic. The skills and performance of understanding in the child improve for that with the advancing age. The illustration in this case is considered not only a benefit to 
improve understanding but also to circumvent certain difficulties. And in that way, according Jian and Ko (2016), an illustration may boost the reading comprehension if it is easy to read. They argue that using illustrations to promote initial reading might help low-ability students read to learn. However, certain conditions are essential for it to play this role fully. In the end, most of the literature on illustration and the comprehension of texts makes it possible to maintain that the illustration is indeed an aid, a beneficial contribution to the process of comprehension and that this one depends on many factors, such as knowledge of the reader, the place of illustration, the time of presentation, the type of illustration (Glenberg \& Kruley, 1992; Glenberg \& Langston, 1992; Gyselinck, 1996; Gyselinck \& Tardieu, 1993; Jamet, 2002). Is this really the case when it comes to text comprehension in children? The results of this study make it possible to answer without ambiguity. While the role of illustration should be somewhat relativized both theoretically and methodologically in order to define its contours even better, it can be considered as a beneficial contribution to understanding in children. Some works done more recently in children and even older ones on the development of narrative structuring (Boisclair, Makdissi, Sanchez, Fortier, \& Sirois, 2004; Makdissi \& Boisclair, 2004a, 2004b; Segui \& Leveille, 1977), reveal that the preschool child will gradually appropriate content and use precisely different situational dimensions in tasks of comprehension and recall of texts. The illustration not only improves the comprehension process but can also be considered as overcoming certain difficulties.

\section{References}

Aaron, P. G., Joshi, R. M., Gooden, R., \& Bentum, K. E. (2008). Diagnosis and treatment of reading disabilities .based on the component model of reading. Journal of Learning Disabilities, 41, 67-84. https://doi.org/10.1177\%2F0022219407310838.

Ammari, L. A. (2015). Effet de l'illustration sur la compréhension et le rappel d'un texte scientifique par des étudiants Algériens. Rôle du niveau de compétence en FLE. Socles, 7, 175-198.

Barriault, L. (2016). Le rôle des histoires dans le développement de l'enfant. Réseau d'information pour la réussite éducative.

Blanc, N. (2009a). Lecture et habiletés de compréhension chez l'enfant. Paris: Dunod.

Blanc, N. (2009b). La compréhension de contes présentés oralement en classes de CP et CE1: quelle utilisation des dimensions situationnelles? L'Année Psychologique, 109, 607-628. https://doi.org/10.4074/S0003503309004023

Blanc, N. (2010). La compréhension des contes entre 5 et 7 ans: Quelle représentation des informations émotionnelles. Canadian Journal of Experimental Psychology, 64, 256-265. https://doi.org/10.1037/a0021283

Blanc, N., \& Brouillet, D. (2003). Mémoire et compréhension: Lire pour comprendre. Paris: In Press.

Blanc, N., \& Brouillet, D. (2005). Comprendre un texte: L'évaluation des processus cognitifs. Paris: In Press.

Blanc, N., \& Tapiero, I. (2002). Construire une représentation mentale à partir d'un texte: Le rôle des illustrations et de la connotation des informations. Bulletin de psychologie, 461, 525-534.

Barnes, M. A., Dennis, M., \& Haefele-Kalvaitis, J. (1996). The effects of knowledge availability and knowledge accessibility on coherence and elaborative inferencing in children from six to fifteen years of age. Journal of Experimental Child Psychology, 61, 216-241. https://doi.org/10.1006/jecp.1996.0015

Bettelheim, B. (1976). Psychanalyse des contes de fées. Traduction de Théo Carlier. Réédition Pocket, 1999.

Boisclair, A., Makdissi, H., Sanchez, C., Fortier, C., \& Sirois, P. (2004). La structuration causale du récit chez le jeune enfant. Actes du 9ème colloque de l'AIRDF, Québec (Canada), 26-28 Août.

Bransford, J. D., \& Franks, J. J. (1972). The abstraction of linguistic ideas: A review. Cognition, 1, 211-249. https://doi.org/10.1016/0010-0277(72)90020-0

Bransford, D., Barclay, J. R., \& Franks, J. J. (1972). Sentence memory : A constructive versus interpretive approach. Cognitive Psychology, 3, 193-209. https://doi.org/10.1016/0010-0285(72)90003-5

Cain, K., \& Oakhill, J. V. (1999). Inference making ability and its relation to comprehension failure ability in young children. Reading and Writing, 11, 489-503. https://doi.org/10.1023/A:1008084120205.

Cèbe, S. (2013). La compréhension de textes n'est pas un jeu d'enfants. Article présenté en séminaire, FPSE Université de Genève.

Chabot R. J., Petros, T. V., \& McCord, G. (1983). Developement and reading ability differences in accessing 
information from semantic memory. Journal of Experimental Child Psychology, 35, 128-142. https://doi.org/10.1016/0022-0965(83)90074-7

Ecalle, J., \& Magnan, A. (2010). L'apprentissage de la lecture et ses difficultés. Paris: Dunod.

Eme, E., Reilly, J., \& Almecija, Y. (2009). Compétences narratives et communicatives chez des personnes en situation d'illettrisme. Revue Européenne de Psychologie Appliquée, 59, 123-138. https://doi.org/10.1016/j.erap.2008.12.001

Gernsbacher, M. A., Varner, K. R., \& Faust, M. E. (1990). Investigating differences in general comprehension skill. Journal of Experimental Psychology: Learning, Memory and Cognition, 16, 430-445. https://doi.org/10.1037//0278-7393.16.3.430

Giasson, J. (1996). La comprehension en lecture. Bruxelles, De Boeck, Pratiques pédagogiques.

Glenberg, A. M., \& Kruley, P. (1992). Pictures and anaphora: evidence for independent processes. Memory \& Cognition, 92, 461-476. https://doi.org/10.3758/BF03199579

Glenberg, A. M., \& Langston, W. E. (1992). Comprehension of illustrated text: pictures help to build mental models. Journal of Memory and Language, 92, 129-151. https://doi.org/10.1016/0749-596X(92)90008-L

Glenberg, A. M., \& Mathew, S. (1992). When Minimalism is Not Enough: Mental Models in Reading Comprehension. Psycholoquy, 3, reading 1-2.

Gyselinck, V. (1995). Les modèles mentaux dans la compréhension de textes: le rôle des illustrations (Thèse de doctorat en Psychologie, Université de Paris V). https://doi.org/10.3406/psy.1996.28911

Gyselinck, V. (1996). Illustrations et modèles mentaux dans la compréhension de textes. L'Année Psychologique, 3, 496-516. https://doi.org/10.3406/psy.1996.28911

Gyselinck, V., Jamet, E., \& Dubois, V. (2008). Therale of working memory components in multimedia comprehension. Applied Cognitive Psychology, 22, 353-374. https://doi.org/10.1002/acp.1411.

Gyselinck, V., \& Tardieu, H. (1993). Modèles mentaux et illustrations dans la compréhension de textes. Communication orale. Laboratoire de Psychologie Expérimentale.

Gyselinck, V., \& Tardieu, H. (1999). The raie of illustration in text comprehension: what, when, for whom, and why? In S. R. Goldman \& H. Van Oostendorp (Eds), The Construction of Mental Representations During Reading, 195-218. New Jersey: Lawrence Erlbaum Associates.

Hollemaert, E. (2013). Quel rôle joue le conte dans le développement de la personnalité de l'enfant et de sa socialisation au cycle 1? Mémoire de Master de Recherche en Littérature. IUFM, Villeneuve d'Ascq.

Jamet, E. (2002). L'apport des nouvelles technologies de l'information et de la communication dans la conception des documents techniques. Psychologie Française, 47, 33-40.

Jamet, E., Le Bohec, O., \& Hidrio, C. (2003). Comment présenter l'information dans les documents numériques éducatifs ? Une approche de psychologie cognitive. Document numérique, 1-2(Vol. 7), 25- 38. https://doi.org/10.3166/dn.7.1-2.25-38

Jian, Y. C., \& Ko, H. W. (2017). Influences of text difficulty and reading ability on learning illustrated science texts for children: An eye movement study. Computers \& Education, 113, 263-279. https://doi.org/10.1016/j.compedu.2017.06.002

Kintsch, W. (1993). Text comprehension, memory and learning. American Psychologist, 49, 294-303. https://doi.org/10.1037//0003-066X.49.4.294

Levie, W. H., \& Lentz, R. (1982). Effects of text illustrations : A review of research. Educational Communication and Technology Journal, 4, 195-233.

Makdissi, H., \& Boisclair, A. (2004a). L'art de raconter chez l'enfant d'âge préscolaire: Une grille de développement du récit. Document III: Rapport de recherche soumis au Programme de partenariats en développement social, Développement des ressources humaines, Canada.

Makdissi, H., \& Boisclair, A. (2004b). La lecture interactive : un lieu d'expansion de l'expression des relations causales chez l'enfant d'âge préscolaire. Document IV: Rapport de recherche soumis au Programme de partenariats en développement social, Développement des ressources humaines, Canada.

Mannes, S. M., \& Georges, S. M. (1996). Effets of prior knowledge on text comprehension: A simple modeling approach. In B. K. Britton \& A. C. Graesser (Eds.), Models of understanding text (p. 115-139). Hillsdale, NJ: 
Lawrence Erlbaum Associates.

Marin, B., \& Legros, D. (2008). Psycholinguistique cognitive. Lecture, compréhension et production de texte. Bruxelles, De boeck - Ouvertures psychologiques. https://doi.org/10.3917/dbu.marin.2008.01

McNamara, D. S., \& Kintsch, W. (1996). Learning from texts. Effects of prior knowledge and text coherence. Discourse Processes, 22, 247-288. https://doi.org/10.1080/01638539609544975

Moravcsik, J. E., \& Kintsch, W. (1993). Writing quality, reading skills, and domain knowledge as factors in text comprehension. Canadian Journal of Experimental Psychology, 47, 360-374. https://doi.org/10.1037/h0078823

Paivio, A. (1986). Mental representations : a dual coding approach. New York: Oxford University Press.

Potocki, A., Bouchafa, H., Magnan, A., \& Ecalle, J. (2014). Évaluation de la compréhension écrite de récits chez l'enfant de 7 à 10 ans: vers des profils de compreneurs. Revue européenne de psychologie appliquée, 64, 229-239. https://doi.org/10.1016/j.erap.2014.08.001

Raponda-Walker, A. (1967). Contes gabonais. Paris, Présence africaine. Réédité en 1996.

Reinwein, J. (1980). Analyse comparative de l'effet de l'illustration sur la lisibilité de six textes illustrés. Cirade, 15, $1-40$.

Reinwein, J. (1988). Lire un texte illustré : Ce que les images d'un texte racontent.... Québec français, 72, 36-42.

Rizk Batien, S. (2009). Effet de l'illustration sur la compréhension des relatives explicatives et déterminantes et de leur ponctuation (Mémoire de maîtrise, Université du Québec à Montréal).

Rossi, J-P. (2008). Psychologie de la compréhension du langage. Bruxelles, De boeck - Ouvertures psychologiques.

Schallert, D. L. (1980). The role of illustrations is reading comprehension. In R. J. Spiro., B. C. Bruce \& W. F. Brewer (Eds.): Theoretical issues in reading comprehension (p. 503-524). Hillsdale. NJ: Lawrence Erlbaum. https://doi.org/10.4324/9781315107493-27

Segui, J. \& Léveillé, M. (1977). Etude sur la compréhension de phrases chez l'enfant. Enfance, 30(1), 105-115. https://doi.org/10.3406/enfan.1977.2637

Symons, S., \& Pressley, M. (1993). Prior knowledge affects text search success and extraction of information. International Reading Association, 251-261. https://doi.org/10.2307/747997

Van Dijk, T. A., \& Kintsch, W. (1983). Strategies of Discourse Comprehension. New York, Academic Press.

Vezin, J. F. (1984). Apport informationnel des schémas dans l'apprentissage. Le Travail Humain, 47, 61-74.

Vezin, L. (1986). Les illustrations, leur rôle dans l'apprentissage des textes. Enfance, 1, 109-126. https://doi.org/10.3406/enfan.1986.2911

Waddill, P. J., \& McDaniel, M. A. (1992). Pictorial enhancement of text memory: Limitations imposed by picture type and comprehension skill. Memory and cognition, 20, 472-482. https://doi.org/10.3758/BF03199580

Yuill, N., \& Oakhill, J. V. (1991). Children's problems in text comprehension: An experimental investigation. Cambridge, MA: Cambridge University Press. https://doi.org/10.1007/978-94-017-2772-3_11

Zérillo, S., \& Brouillet, D. (2002). Résumé pour comprendre. Mémoire de recherche de maîtrise. Département des Sciences de l'éducation. Université Paul Valéry Montpellier III.

Zwaan, R. A., \& van Oostendorp, H. (1993). Do readers construct spatial representation in naturalistic story comprehension? Discourse Processes, 16, 125-143. https://doi.org/10.1080/01638539309544832

\section{Copyrights}

Copyright for this article is retained by the author(s), with first publication rights granted to the journal.

This is an open-access article distributed under the terms and conditions of the Creative Commons Attribution license (http://creativecommons.org/licenses/by/4.0/). 